\title{
PERANAN PEMILIHAN STRATEGI DAN STILISTIKA DALAM IKLAN DI TELEVISI
}

\author{
Mezia Kemala Sari \\ Universitas Muhammadiyah Sumatera Barat \\ Jln. Pasir Kandang No. 4 Padang Sumatera Barat \\ No. Tlp. (0751) 481645, No.HP.082174414411,E-mail: purpelicious.lola@gmail.com
}

\begin{abstract}
Abstrak
Televisi adalah salah satu media terbaik saat ini yang dapat menghubungkan tujuan-tujuan dari para produsernya dengan kebutuhan konsumen. Tayangan televisi sangat penting sehingga konsumen dapat dengan mudah mendapatkan hal-hal baru melalui tayangan televisi seperti iklan. Iklan menjadi sangat penting ketika produser ingin menawarkan produk atau jasa. Hal ini dapat dengan mudah dicapai dengan membuat iklan di televisi untuk mendapatkan perhatian pembeli yang potensial. Tujuan utamanya adalah untuk menyampaikan pesan iklan tersebut dengan menarik yang dikemas untuk menjaring konsumen. Hal-hal yang harus dipertimbangkan dalam memilih strategi adalah relevansi akan produk itu sendiri, pesaing dan target pasar juga harus jelas. Iklan harus memerhatikan aspek iklan, yaitu stilistika. Dalam mendapatkan keunikan gaya, produsen dapat menggunakan penggunaan strategi bahasa seperti slogan, pemilihan karakter yang menarik, pemilihan strategi yang tepat dan juga menggunakan elemen iklan lainnya. Pemilihan strategi iklan akan menentukan penyampaian gaya bahasa pesan melalui bentuk kreativitas untuk mendapatkan respons konsumen yang lebih baik.
\end{abstract}

Kata kunci: strategi pemilihan, gaya bahasa iklan, televisi

\begin{abstract}
The Role of Selection and Stylistics Strategies in Advertising on Television. Television is one of the best medium today that can connect producers'goals with consumers' needs. The televisions' impressions are crucial so that consumers can easily get new things through the television's impressions like advertisment. Advertisment becomes very important when producer wants to offer product or service. It can be easily achieved by making advertisment on television to get potential buyers'attention. The main goal is to deliver advertising messages by using attractive packaged to stimulate consumers. The things that should be considerated in choosing strategies are the relevancies to product itself, competitors and also clear target market. Advertisement should pay attention to the Stylistics' advertising aspects. In getting the uniqueness of style, producers can use language strategies usage like slogans, selection of interesting characters, selection of appropriate strategies and also using other advertising elements. The selection advertisements'strategies will determine conveying stylistics'messages through form of creativity to get the better consumer response.
\end{abstract}

Keywords: selection strategy, stylistics'advertising, television

\section{PENDAHULUAN}

Hampir setiap hari masyarakat menonton televisi. Televisi dewasa ini telah menjadi sarana atau media yang paling banyak dipilih masyarakat dalam rangka memenuhi kebutuhan akan informasi seperti berita, tayangan hiburan sejenis film atau acara musik hingga sarana untuk menambah ilmu pengetahuan atau belajar dengan mengikuti tayangan yang menginspirasi misalnya acara 
masak-memasak untuk ibu-ibu dan remaja puteri yang saat ini sudah bisa didapatkan dengan lebih mudah di televisi. Terlebih lagi saat ini terdapat banyak pilihan tontonan yang dapat dipilih secara mudah. Banyak perusahaan yang berlomba-lomba menyajikan tayangan terbaik mereka dalam rangka menarik minat penonton atau konsumen untuk menjadi pemirsa setia mereka. Televisi sangat berperan penting saat sekarang ini dan jauh lebih efektif dalam menyampaikan pesan dan informasi kepada konsumen jika dibandingkan dengan media atau sarana lainnya seperti radio dan surat kabar. Masyarakat pada umumnya lebih senang dengan kepraktisan akan informasi dan juga hiburan yang dapat dilihat langsung dari televisi. Televisi memanjakan konsumen secara audio dan visual. Misalnya saja tayangan mengenai suatu peristiwa bencana. Jika kita mendengarkan berita dari radio atau hanya dengan membaca tabloid mengenai tragedi tersebut, rasa ingin tahu tadi dapat dipuaskan dengan tayangan di televisi. Di sinilah peran penting wartawan dan para pengumpul berita dapat dirasakan masyarakat. Suatu peristiwa seperti gempa dan tsunami di Aceh pada tahun 2004 silam, di saat yang tak berselang lama, dapat disaksikan oleh orangorang yang ada di Sulawesi ataupun Papua. Itulah hebatnya televisi. Semua orang di dunia bisa saling tahu perkembangan dan peristiwaperistiwa penting yang terjadi di berbagai belahan dunia hanya dengan menonton televisi di rumah ataupun di kantor.

Rasanya tak salah jika khalayak menemukan banyak produsen sekarang memilih televisi sebagai sarana pengiklan terbaik. Alasannya sangat mendasar karena dengan beriklan di televisi, mereka dapat menyampaikan pesan langsung ke konsumen yang sedang menonton televisi. Dewasa ini banyak sekali terdapat iklan-iklan yang dikemas sedemikian rupa dan semenarik mungkin untuk mendapatkan perhatian dari konsumennya. Mulai iklan produk susu bayi, iklan sabun pembersih wajah, iklan sabun, iklan shampo, iklan pompa air, iklan alatalat kebutuhan rumah tangga, iklan makanan ringan, iklan kosmetik, iklan pewangi pakaian, iklan detergen, iklan cat, iklan elektronik, iklan rokok hingga iklan jasa dan juga layanan masyarakat. Semua informasi-informasi bisa langsung sampai pada masyarakat hanya dengan beriklan di televisi. Dengan tayangan yang bisa hanya beberapa detik saja, produsen telah berhasil menyampaikan pesannya pada masyarakat luas.

Selanjutnya, mengenai apa dan bagaimana sebuah pesan bisa disampaikan melalui iklan inilah yang akan membuat satu iklan berbeda dengan iklan yang lain walaupun jenis produknya sama. Misalkan saja, iklan susu bayi yang belakangan ini sangat menarik perhatian konsumen terutama ibu-ibu. Iklan antara produk 'Bebelac' dengan 'Nutrilon' pasti berbeda. Walaupun dalam iklan tersebut samasama menayangkan seorang ibu dengan bayi atau balitanya, tetap saja gaya dan cara produsen berbeda dalam membuat cerita di iklan tersebut agar menjadi menarik. Namun, pesan yang ingin disampaikan tetaplah sama, yakni agar konsumen mau memilih produk mereka. Inilah kiranya yang menjadi pembahasan dalam artikel ini, yakni fungsi dan peranan pemilihan strategi pada iklan dan juga peranan stilistika atau gaya pada iklan yang ditayangkan di televisi secara umum. Di sini, penelitian tidak akan hanya bertumpu pada satu iklan atau satu produk, tetapi lebih pada iklan yang populer secara umum saat ini untuk dilihat pentingnya peranan dari strategi periklanan dan juga gaya iklan tersebut. 


\section{PENTINGNYA PERANAN PEMILIHAN STRATEGI IKLAN DI TELEVISI}

Berbicara mengenai strategi, hal yang langsung bisa ditangkap adalah mengenai cara atau siasat dengan banyak pertimbangan. Iklan bukan hanya sekadar tayangan sesaat untuk mempromosikan suatu produk atau jasa. Untuk membuat sesuatu yang berbeda dan meninggalkan kesan dan pesan pada konsumen itulah yang disebut dengan strategi. Iklan juga harus memiliki strategi. Keberhasilan suatu iklan dapat ditentukan dari strategi yang digunakan karena strategi memegang peranan yang vital dan ia merupakan dasar membangun merek. Salah satu fungsi utama dari strategi adalah menjaga agar periklanan dan elemen pemasaran berada dalam jalur yang sesuai atau tepat dan juga membangun kepribadian dan ciri khas merek secara jelas dan konsisten. Dengan kata lain, strategi mewakili jiwa sebuah merek produk dan akan menjadi elemen penting untuk keberhasilannya (Roman, Maas, dan Nisenholtz, 2005:25).

Menurut Suhandang (2005:22), strategi suatu iklan harus mampu menjawab pertanyaan dasar dari rancangan sebuah kampanye periklanan yang biasa dirumuskan dengan $5 \mathrm{~W}$ $+1 \mathrm{H}$, yakni What (Apa tujuan iklan); Who (Siapa target uklan yang akan dijangkau); When (Kapan iklan dipasang); Where (Di mana iklan dipasang); Why (Mengapa harus demikian); dan How (Bagaimana bentuk iklannya). Seluruh elemen ini wajib untuk dipertimbangkan dalam rangka menciptakan iklan yang efektif. Efektif di sini dalam artian pesan yang ingin disampaikan akan tercapai dengan benar. Tentu saja tidak semudah itu, karena ada banyak pertimbangan lain yang harus diperhatikan sebelum membuat iklan. Menurut Batey (2003:56), kunci pokok yang harus diketahui oleh pemasar sebelum merumuskan strategi periklanan adalah pengetahuan yang cukup tentang produk, persaingan pasar atau kompetitor, dan juga analisis mendalam mengenai konsumen. Seluruh aspek ini harus terpenuhi terlebih dahulu agar iklan yang diciptakan akan sesuai hasilnya dengan target yang hendak dicapai.

Sebagai konsumen, kita tentu dapat memilih dan menilai produk mana yang lebih bagus melalui iklan yang baik dan menarik. Tak dapat dipungkiri bahwa iklan memberikan pengaruh yang besar terhadap konsumen dan gaya penyampaian pesan di iklan yang menarik akan memberikan pengaruh yang berbeda terhadap keinginan konsumen untuk membeli produk tersebut. Kembali mengacu pada teori iklan yang disampaikan oleh Batey (2005:11), bahwa hal utama yang penting sebelum merumuskan suatu iklan adalah pengetahuan tentang produk (marketing Brief). Hal ini senada dengan Madjadikara (2004:12) yang mengatakan bahwa informasi mengenai produk atau jasa yang akan diiklankan harus termuat dalam marketing brief yang dibuat oleh klien yang secara garis besar meliputi: merek (brand) baru atau lama; penjelasan singkat mengenai fitur produk (product knowledge); keunggulan produk dibanding kompetitor; target audience berupa segmentasi yang dimaksud oleh produk dengan melakukan penelitian atau observasi secara global mengenai selera konsumen sehingga produsen bisa memenangkan perhatian konsumen dalam hitungan detik; analisis produk dengan membandingkan dengan produk pesaing, kondisinya hingga kecenderungan pasar; hingga kompetitor yang penting untuk diperhatikan terlebih dahulu mengenai keunggulan dan kelemahan iklannya.

Setelah mempertimbangkan pentingnya marketing brief sebelum membuat iklan, hal 
selanjutnya yang juga harus diperhatikan adalah rangkuman kreatif (creative brief). Suatu iklan sebisa mungkin harus kreatif dan inovatif karena iklan yang hanya tampil beberapa saat di televisi harus mampu menyita perhatian konsumen. Cara yang paling efektif untuk dapat menarik perhatian konsumen ini adalah dengan menciptakan iklan yang kreatif dan tidak membosankan sehingga pesan iklan akan tersampaikan bahkan akan meninggalkan efek yang lama bagi konsumen karena selalu ingat akan gaya iklan yang disajikan. Tentu saja tiap agensi periklanan akan menyajikan model rangkuman kreatif yang berbeda-beda yang akan sangat bergantung pada kebutuhan produk yang akan diiklankan. Pemasaran tidak membuat rumus yang melarang adanya perubahan sehingga hal ini menstimulasi timbulnya ide-ide kreatif iklan.

Menurut Roman, Maas, dan Nisenholtz (2005:36), hal-hal yang biasanya terdapat dalam sebuah rangkuman kreatif salah satunya adalah tujuan atau sasaran untuk mengomunikasikan informasi dan membangun persepsi terhadap suatu merek. Selain itu, alasan konsumen untuk percaya adalah hal yang juga menjadi prioritas. Untuk itu, penting untuk dipertimbangkan banyak hal dalam menciptakan suatu persepsi dari sudut pandang konsumen. Selanjutnya, yang tidak kalah penting adalah tone atau gaya. Pemilihan bahasa dan gaya komunikasi yang khas akan meninggalkan kesan yang lebih mendalam daripada gaya bahasa yang biasa. Penggunaan slogan atau kata-kata yang menjadi ciri khas suatu produk akan lebih baik bagi suatu merek karena konsumen akan lebih mudah untuk mengingatnya. Misalnya saja slogan pada iklan perusahaan asuransi Prudential dengan slogan 'Always listening.. Always understanding'. Misalnya juga iklan makanan cepat saji Mc.Donals, yakni 'I'm lovin' it' ataupun iklan rokok Djarum Black dengan slogannya 'Think Black' dan masih banyak lagi produk yang disajikan dengan slogan-slogan yang membuatnya mudah diingat oleh konsumen. Ditambah lagi dengan back sound dan nada yang membuatnya lebih menarik dan khas akan membuat suatu produk bisa cepat diterima dan diingat konsumen. Jadi, jelaslah bahwa dalam satu iklan saja, diperlukan pertimbangan-pertimbangan dan pemilihan strategi yang tepat yang harus dirumuskan terlebih dahulu untuk mencapai hasil yang memuaskan.

Jadi, tak heran jika kita melihat iklan di televisi saat ini begitu beraneka ragam. Masing-masing produk seperti berlombalomba untuk membuat iklan semenarik mungkin. Misalnya, jika kita melihat iklan susu bayi, tema umum yang diambil oleh produsen tentunya adalah dengan menampilkan bayi atau balita yang sehat, berkulit mulus, ceria, fisik yang sempurna dan juga pintar sehingga hal ini nantinya yang akan membuat semacam opini di publik bahwa dengan mengonsumsi produk susu bayi tersebut bayi atau anak kita akan bisa lebih kurang seperti anak-anak yang ada di dalam iklan tersebut. Salah satu pengiklan susu bayi yang sering tayang belakangan ini adalah produk Bebelac dengan mengeluarkan ide kreatifnya, yakni adanya even 'Bebestar'. Pada iklan kita bisa melihat sejumlah anak (balita) yang sepertinya mahir dalam suatu profesi seperti menyanyi, memainkan alat musik hingga menari. Kita sebagai konsumen awam akan merasa tergelitik dengan tingkah pola anak-anak yang terlihat sangat pintar tersebut. Inilah strategi yang digunakan oleh produsen bahwa dengan mempertunjukkan anak-anak yang pintar dan berbakat tersebut bisa semakin 
terasah kepintarannya dengan meminum prosuk mereka. Mereka juga menjelaskan secara singkat fitur atau kandungan gizi penting yang dibutuhkan anak. Artinya, produsen telah menstimulasi konsumen dengan memberikan gambaran bahwa dengan mengonsumsi produk mereka, akan tercipta anak-anak yang pintar dan kreatif seperti mereka yang ada di iklan hingga konsumen akan terpengaruh dan membeli produk tersebut untuk bayi-bayi mereka.

Contoh lain adalah iklan sepeda motor yang juga marak di televisi. Misalnya merek Yamaha dengan slogannya 'Selalu di Depan' menampilkan iklan yang juga bisa menciptakan opini baru untuk konsumen. Bahwa dengan menggunakan motor Yamaha, kita bisa menjadi terdepan karena kencangnya laju motor tersebut hingga mengalahkan pesaing yang lain. Strategi lain yang sepertinya juga sangat mempengaruhi adalah tokoh dalam iklan. Semakin terkenal orang yang memerankan iklan tersebut, nampaknya iklan tersebut akan semakin diminati. Tentu saja karakter-karakter yang sudah terkenal dan bercitra baik akan memberikan efek positif terhadap pencapaian tujuan iklan. Hal ini akan memberikan contoh pada konsumen bahwa sang tokoh juga memakai produk yang sama sehingga mereka akan tertarik untuk memiliki produk yang sama.

Strategi-strategi di atas tak selalu diikuti oleh produsen mengingat ide-ide kreatif selalu muncul dan dapat digunakan kapan saja mengingat tidak adanya pembatasan yang ekstrem terhadap iklan kecuali sebagaimana yang berlaku pada Undang-Undang Periklanan yang biasanya lebih bersifat prinsip. Untuk membuat iklan menjadi lebih menarik, produsen juga berupaya untuk menggunakan berbagai macam pendekatan. Salah satu hal yang lazim kita temui dalam iklan adalah berupa 'lanturan'.
Menurut Hakim (2005:31), terdapat beberapa pendekatan yang dapat dipilih dan digunakan oleh produsen untuk membuat iklan menjadi semakin mengesankan seperti lanturan. Salah satunya adalah plesetan.

Sekarang ini kita banyak menemukan iklan yang menggunakan plesetan oleh pemeran di dalamnya. Tujuan dari pemilihan strategi ini adalah untuk memberikan kesan humor yang bisa membuat konsumen tertawa ketika mendengar plesetan karena relevansinya. Umumnya, relevansi dalam konteks ini mengacu pada kata aslinya yang kemudian diplesetkan. Di samping plesetan dengan katakata, terdapat juga sindiran pada produk saingan secara tidak langsung berupa tampilan ikon yang telah menjadi khas produk saingan. Kita bisa menemukan gaya ini pada iklan provider yang saling bersaing seperti antara Telkomsel, Indosat, XL, Axis, dan Esia yang telah memiliki ikon masing-masing yang salah satunya adalah kekhasan warna masing-masing. Pada iklan Esia yang dominan warna hijau, dapat kita lihat ketika orang-orang yang mengenakan warna lain (sebagai simbol dari masing-masing provider) sibuk mencari sinyal yang hilang, warna hijau seperti mudah mendapatkan sinyal. Ini semacam strategi iklan yang digunakan oleh produsen untuk membandingkan secara tidak langsung keunggulan produk mereka dengan produk saingan.

Selanjutnya, visual produk dan juga headline kata-kata akan memuat juga makna tertentu yang akan semakin mencirikan kekhasan produk yang ditawarkan. Yang tak kalah penting berikutnya adalah penggunaan logo. Logo akan berperan sebagai sumber ide dalam menyampaikan pesan periklanan. Penggunaan logo yang menarik dan unik akan membuat konsumen terkesan dan mudah 
untuk mengingat produk dalam iklan. Begitu pula dengan peranan tokoh sebagai endoser. Sepertinya dari dulu hingga sekarang produsen berlomba-lomba untuk menemukan figur atau tokoh yang pas untuk memerankan iklan untuk maksud tertentu. Semakin terkenal dan berpengaruhnya tokoh yang dipilih, nilai dari iklan tersebut akan semakin tinggi. Misalnya saja iklan sepeda motor yang memakai langsung pembalap dunia sekelas Valentino Rossy yang tentunya membuat iklan tersebut semakin berkelas dan terkesan serius. Begitu juga ketika iklan-iklan lain yang menghadirkan pemain bola dunia yang sekarang bisa dengan mudah kita lihat dalam iklan suatu produk. Hal ini wajar saja mengingat produsen harus menciptakan sesuatu yang berani dan menarik minat konsumen. Penggunaan orang terutama yang menjadi publik figur dalam penyampaian pesan telah menjadi strategi yang saat ini sering digunakan produsen.

Dramatisasi cerita dalam sebuah iklan juga merupakan strategi yang unik. Kita bisa ambil contoh iklan produk rokok yang pada umumnya tayang pada malam hari. Jika kita perhatikan, iklan rokok tidak pernah ada yang menayangkan tokoh sedang menghisap rokok, melainkan menghadirkan cerita yang berbeda seperti petualangan seorang pria yang meninggalkan kesan 'jantan' karena kemampuannya menaklukkan medan. Ada juga kisah persahabatan setia antara sekelompok pria yang saling membantu satu sama lain dan sebagainya. Hal ini merupakan siasat dari produsen rokok dalam rangka mematuhi rangkaian aturan khusus produk rokok yang cukup menyulitkan. Pada iklan rokok dilarang untuk memvisualisasikan wujud dan juga bungkus rokok serta tidak boleh terangterangan mengajak konsumen untuk merokok.
Hal ini sangatlah berbeda dengan iklan produk lain yang secara mudahnya memilih strategi yang diinginkan. Ditambah lagi dengan aturan jam tayang untuk iklan rokok yang hanya boleh tayang sekitar pukul 21.30 hingga 05.00 pagi. Ada banyak penelitian yang telah dilakukan terhadap strategi iklan pada rokok ini dengan menggunakan teknik tata ungkap audio dan visual dan teknik analisis isi. Karana (2007:74) dalam penelitian skripsinya menemukan bahwa terdapat beberapa strategi yang umumnya digunakan oleh produsen rokok dalam rangka mengomersialkan produk mereka, yakni terdapatnya kombinasi beberapa strategi seperti slice oflife, storyline, dan close up. Strategi slice of life sering digunakan dengan memanfaatkan penggalan dari kehidupan sehari-hari dalam bersosialisasidenganmasyarakatataukomunitas lain (Studi Antar Kasus: Rokok A-Mild, Star Mild, dan L.A.Lights). Strategi atau siasat story line digunakan untuk membuat khalayak atau konsumen tertarik untuk mengikuti alur cerita iklan yang pada umumnya menarik layaknya penggalan film pendek. Begitu juga dengan strategi close up yang lebih menonjolkan kejelasan ekspresi pemeran iklan yang rata-rata menarik. Penggunaan kombinasi strategi tentu saja akan saling mendukung dan menciptakan iklan yang menarik. Inilah tantangan yang harus dilakukan produsen rokok untuk selalu kreatif mengingat banyaknya aturan periklanan yang harus dipatuhi.

Masih banyak lagi strategi yang bisa dipilih oleh produsen produk untuk mengiklankan produk mereka. Pendekatan budaya juga bisa digunakan sebagaimana yang sering kita lihat dengan adanya penampilan sekilas tari-tari tradisional, rumah-rumah adat, dan tokoh-tokoh dalam iklan yang berpakaian adat. Hal ini juga bisa untuk menyampaikan 
pesan iklan selama masih ada relevansi dengan produk yang ditawarkan.

Namun, di balik banyaknya strategi iklan yang dapat dipilih atau dikombinasikan tersebut di atas ada satu strategi yang sepertinya juga banyak digunakan dalam periklanan, yakni Humor. Ternyata penggunaan strategi ini tidak boleh sembarangan dan harus berhati-hati agar tidak sampai melanggar aturan periklanan. Menurut Max Sutherland dalam Marketing (2004:50), iklan yang lucu akan mengurangi unsur pesan yang penting. Produsen harus berhati-hati jika ingin menggunakan pendekatan ini. Kekhawatirannya adalah pada focus audience yang justru akan tertuju pada 'lucunya' iklan bukan pada inti pesannya. Selanjutnya, ia mengatakan bahwa iklan lucu hanya akan efektif jika persepsi atau anggapan orang terhadap pesan sudah dianggap positif. Tidak ada yang salah dengan strategi ini, namun produsen sebaiknya harus melakukan observasi terlebih dahulu mengenai persepsi konsumen terhadap produknya.

Menurut Suyanto (2004:22), ada tren baru dalam strategi pengiklanan yang baik, yakni tren iklan ke depan yang diarahkan pada emosi. Para peneliti iklan pun telah mengenal secara baik bahwa iklan yang berpengaruh secara positif khususnya pada 'perasaan' dan 'emosi' target akan dapat sangat sukses untuk situasi dan produk tertentu. Hal ini senada dengan John Hegarty, seorang pakar iklan dari Amerika yang menyebutkan bahwa globalisasi membuat produk-produk tersebut memiliki kualitas yang serupa. Untuk itu industri sekarang banyak yang bersaing dengan menyentuh gengsi dan emosi konsumen. Dengan kata lain, kepercayaan dan keyakinan (emotional selling proposition) dari konsumen sekarang ini lebih diutamakan untuk mendapatkan perhatian konsumen dan bukan hanya dari keunggulan produk yang ditawarkan. Semakin besar ketertarikan konsumen secara emosi, iklan akan lebih mudah mengatasi perbedaan-perbedaan kecil yang terkandung dalam setiap produk (Batey, 2003:35).

Jadi, jelaslah mengapa strategi iklan sangat penting untuk diperhatikan dalam sebuah periklanan produk ataupun jasa. Namun, harus diingat bahwa hal yang paling sederhana sekaligus yang paling sulit dalam pembuatan iklanadalah harus memperhatikanaspek 'pesan'. Dalam teori ilmu komunikasi, kepenerimaan komunikan terhadap pesan yang disampaikan oleh komunikator menjadi dasar penilaian akan keberhasilan suatu proses komunikasi (Effendi, 1981:11). Dengan kata lain, penetapan strategi pesan periklanan merupakan suatu keputusan yang sangat strategis yang mampu menjamin sukses atau gagalnya suatu iklan. Dalam hal ini kampanye iklan akan sangat efektif jika didasarkan pada satu tema besar saja sehingga kampanye iklan itu sendiri akan berperan besar dalam pencapaian pangsa pikiran (mind share) dan tentu saja pangsa pasar (market share).

Masih banyak lagi jenis strategi atau siasat yang bisa digunakan oleh produsen dalam mengiklankan produk atau jasa yang hendak dilemparkan kepada konsumen. Biasanya strategi dipilih dan ditetapkan dengan mengombinasikan hal-hal penting dan relevan dengan tujuan serta pesan yang hendak disampaikan. Selanjutnya, produsen bisa melihat respon dari konsumen setelah menghadirkan iklan di media televisi dengan melakukan observasi secara langsung. Namun, harus selalu diingat bahwa produk itu sendiri adalah citra yang menjadi ukuran personaliti seseorang dan periklanan adalah media pencitraan yang paling canggih saat ini. Iklan adalah pembentuk citra maka citra adalah 
simplifikasi, cenderung fokus, single minded (Indrarto, Kompas, Kamis, 6 Maret 2003).

\section{PENGARUH STILISTIKA IKLAN DI TELEVISI}

Sebagaimana yang telah dijelaskan secara ringkas di atas mengenai pentingnya pemilihan strategi yang berfungsi sebagai pendukung utama dalam sebuah penyampaian pesan, hal ini menjadikan tersampaikannya pesan menjadi tujuan utama yang harus diperhatikan oleh pembuat iklan. Secara empiris, hampir semua kampanye periklanan yang bisa fokus pada satu tema besar hampir selalu sukses dengan rancangan mereka. Menurut Durianto dkk (2003:14), hampir semua Advertising Campaigns telah membuktikan keberhasilannya dengan hanya menggunakan satu tema saja. Hal ini juga dijelaskan lebih lanjut oleh Wibowo (2003:47), yang mengatakan bahwa untuk menentukan tema yang tepat diperlukan suatu analisis terhadap produk yang tepat dan dilakukan secara cermat dan komprehensif terkait dengan fitur dan keadaan produk, harga, sasaran pasar, aspek demografis, tingkat persaingan, dan unsur-unsur lainnya.

Setelah penentuan tema dan pemilihan strategi yang tepat, sekarang kita akan melihat bagaimana pengaruh 'gaya' yang disajikan oleh pembuat iklan atau produsen terhadap konsumen yang dalam hal ini akan dilihat dari sudut pandang stilistika. Stilistika pada dasarnya merupakan ilmu yang membahas mengenai gaya dari pengarang sebagaimana yang dijelaskan oleh Verdonk (2002:4) bahwa stilistika adalah analisis ekspresi yang khas (dalam bahasa) dan kajian mengenai tujuan dan efek. Secara garis besar, inti stilistika adalah menemukan cara pengungkapan pikiran melalui bahasa secara khas yang memperlihatkan jiwa dan kepribadian penulis. Lebih lanjut Verdonk (2002:8) juga menjelaskan bahwa masalah gaya tidak hanya semata untuk membahas tujuan dari sisi pembuat, tetapi juga efek yang dirasakan oleh konsumen (foregrounding), yakni efek psikologis yang mempengaruhi konsumen. Bila diterjemahkan dalam dunia periklanan, kekhasan suatu format iklan mesti sangat diperhitungkan oleh pembuatnya karena ini akan menjadi ajang untuk menarik pembeli atau konsumen. Secara garis besar, stilistika iklan adalah menemukan cara penyampaian visual, bahasa, format, dan sebagainya yang tentu saja menjadi ciri khas produknya.

Seiring dinamika pasar, tentu saja banyak jenis iklan yang bisa kita perhatikan. Hal yang menarik adalah salah satunya dari sisi gaya penyampaian yang beragam di televisi. Satu hal yang bisa dipastikan adalah bahwa produsen akan membuat iklan sedemikian rupa untuk menarik perhatian dan minat konsumen agar terpengaruh untuk membeli dan menggunakan produk ataupun jasa yang diiklankan.

Di antara beberapa bentuk gaya yang digunakan, berikut beberapa gaya yang bisa disimpulkan dari iklan secara umum:

\section{Dari Segi Pemilihan Bahasa}

Umumnya iklan adalah berbahasa. Maksudnya, terdapat penggunaan bahasa baik itu yang diucapkan oleh tokoh dalam iklan maupun kata-kata berupa slogan yang hanya dituliskan. Penggunaan atau pemilihan bahasa ini akan menciptakan kekhasan sendiri bagi produk. Terutama dengan adanya sloganslogan yang pada tiap episode iklan selalu dihadirkan agar konsumen selalu ingat. Seperti iklan Yamaha dengan slogannya 'Selalu di depan' akan selalu dituturkan oleh karakter dalam iklan. Contoh lainnya salah satu iklan air 
conditioner (AC) dengan slogannya 'Sayonara panaaass...'. Hal ini akan semakin membuat konsumen mudah untuk mengingat produk. Gaya ini merupakan pilihan dari produsen untuk menunjukkan kekhasan dari produk yang ditawarkan.

\section{Dari Segi Karakter atau Penokohan}

Pada beberapa produk, ada karakter atau tokoh yang selalu hadir dan tidak diganti. Upaya ini merupakan strategi untuk membuat gaya atau ciri khas iklan tersebut tidak mudah hilang. Biasanya artis atau tokoh terkenal yang diangkat sebagai ikon dari produk tersebut seperti atlet Ade Rai pada iklan ESIA. Ade Rai sudah membintangi beberapa kali episode iklan provider tersebut hingga ia dikenal sebagai ikonnya. Begitu juga dengan artis dan penyanyi berambut panjang dan hitam, Anggun C. Sasmi yang belakangan sering membintangi iklan shampo Pantene. Hal ini membuktikan bahwa produsen bermaksud untuk memberikan ciri khas tentang produknya melalui karakter yang sama atau statis.

\section{Dari Segi Pemilihan Strategi Periklanan}

Gaya khas dari iklan selanjutnya bisa kita lihat dari pemilihan strategi iklan. Sebagaimana yang telah dipaparkan pada bagian peranan pemilihan strategi iklan di atas bahwa pembuat iklan cenderung menggunakan strategi yang bisa saja sama atau sengaja diubah pada iklan yang hendak disajikan. Misalnya iklan produk rokok Sampoerna Hijau. Hampir pada tiap iklannya ditampilkan sepenggal kisah atau kilasan kisah sebuah geng persahabatan (teknik story line) yang menarik untuk diikuti. Terlepas dari relevansi antara produk dan alur cerita, tema kecil ini berhasil memikat konsumen yang tertarik dengan penggalan cerita yang selalu dibuat kreatif dan dikemas lucu hingga konsumen selalu menantikan penggalan ceritacerita baru dari iklan produk tersebut. Begitu juga uniknya persaingan strategi iklan dari beberapa provider yang selalu memperlihatkan persaingannya yang membuat tiap pemilihan strategi iklan tersebut menjadi menarik dan menyenangkan untuk diikuti.

\section{Dari Segi Unsur Pelengkap Iklan}

Unsur pelengkap di sini adalah seperti latar lagu atau sound clip yang khas, baik itu lagu yang sudah terkenal atau suara-suara tambahan yang lucu yang akan menjadi khas dari produk tersebut. Inilah kreativitas yang akan menjadi kekhasan dari iklan itu sendiri.

Kekhasan gaya-gaya tersebut merupakan bentuk kreativitas dari pengiklan dalam rangka menarik minat dan perhatian dari konsumen. Tujuan utama adalah untuk mempengaruhi konsumen secara psikologi dan memberikan kesan atau efek yang menarik bahwa produk yang dimaksud benar-benar bagus. Itulah efek psikologis (foregrounding) yang diharapkan bisa tercapai oleh pembuat iklan melalui strategi-strategi iklan yang menarik dan mempunyai kekhasan gaya.

\section{PENGARUH PEMILIHAN STRATEGI DAN PENGGUNAAN STILISTIKA IKLAN DI TELEVISI DALAM KAITANNYA DENGAN PESAN DAN KREATIVITAS}

Terdapat banyak strategi atau siasat dalam menganalisis sebuah produk untuk mencari dan menemukan pesan apa yang ingin disampaikan kepada konsumen (what to say). Pemilihan strategi tersebut tentu saja bergantung pada jenis produk, kompetitor, dan juga target pasar. Semakin strategi yang dipilih itu sesuai, menarik, dan bagus, akan 
semakin meningkatkan minat konsumen terhadap produk atau jasa yang ditawarkan. Begitu juga sebaliknya, jika pemilihan strategi tidak sesuai dengan salah satu faktor penting seperti kurang relevan dengan target pasar, iklan bisa dinyatakan tidak akan memberikan pengaruh yang berarti atau bisa disebut gagal. Jadi, pembuat iklan harus benar-benar memperhatikan apa dan bagaimana seharusnya iklan itu dibuat dengan pemilihan strategi yang tepat dan tentu saja sesuai dengan yang diharapkan dan dibutuhkan oleh konsumen sehingga maksud dan tujuan bisa tercapai.

Begitu juga dengan peran stilistika iklan terhadap pencapaian maksud dan tujuan iklan. Agar suatu iklan produk atau jasa bisa diterima dan disambut masyarakat dengan apresiasi yang bagus, pembuat iklan juga harus memberikan sesuatu yang khas kepada konsumen agar konsumen tidak cepat puas dengan produk yang ditawarkan. Kekhasan bisa dilakukan dengan banyak metode atau cara seperti bahasa yang digunakan, misalkan slogan yang menciptakan kekhasan tersendiri terhadap citra dan penamaan produk. Bisa juga melalui pemilihan dan kombinasi strategi iklan yang tepat sasaran, bisa juga dengan memenuhi aspek-aspek iklan yang lain sehingga suatu iklan akan mencakup banyak hal yang menarik perhatian konsumen. Untuk mencapai hasil yang diharapkan, pembuat iklan harus melakukan pengamatan terutama untuk menghadapi kompetitor dan juga tidak meninggalkan aspek target pasar yang juga sangat penting.

Jika seluruh aspek telah tercakupi, tujuan dasar iklan pasti akan tercapai, yakni pesan. Pesan adalah hal yang utama yang harus dicapai sebuah iklan. Pesan umum adalah menarik minat dan mempengaruhi konsumen untuk membeli produk. Untuk mencapai ke tujuan akhir itulah diperlukan kreativitas yang tinggi dari si pembuat iklan dalam rangka mengampanyekan produknya sehingga semua sesuai dengan target atau yang diharapkan. Untuk itu, jelaslah pemilihan strategi dan stilistika iklan sangat memberikan pengaruh yang besar terhadap tercapainya pesan sebagai tujuan dari iklan.

\section{SIMPULAN}

Sebagai bentuk penyampaian yang memotivasi konsumen untuk membeli suatu produk dan jasa, iklan terdiri atas beberapa unsur penting, seperti unsur gagasan atau ide, khalayak, sponsor, dan biaya iklan. Hal ini sesuai dengan pentingnya unsur $5 \mathrm{~W}+1 \mathrm{H}$ yang harus terpenuhi dalam sebuah iklan.

Tujuan dasar iklan adalah untuk mempengaruhi atau memotivasi calon pembeli potensial agar tertarik dengan tawaran produk atau jasa. Untuk itu, digunakanlah beberapa strategi yang dianggap penting dan menarik untuk disajikan dalam rangka mencapai tujuan tersebut. Pemilihan metode atau strategi iklan tergantung pada kebutuhan produsen dan konsumen dengan memperhatikan beberapa aspek penting seperti bentuk produk, kompetitor, dan target pasar. Hal ini penting untuk diperhatikan oleh pembuat iklan untuk memastikan bahwa produk yang akan ditawarkan pada konsumen relevan dan sesuai dengan kebutuhan masyarakat banyak.

Cara penyampaian iklan yang khas akan memberikan nilai tambah dan akan membuat iklan tersebut menjadi menarik. Untuk itu, stilistika iklan penting untuk diperhatikan, yakni bagaimana suatu iklan bisa memiliki kekhasan tersendiri baik itu melalui bahasa, pemilihan strategi, pemilihan tokoh atau karakter ataupun unsur-unsur tambahan lain sehingga nantinya 
ketika konsumen melihat iklan tersebut di televisi akan merasakan efek psikologis (foregrounding) seperti yang diharapkan pembuat iklan. Dengan kata lain, iklan tersebut berhasil menciptakan persepsi baru dan bisa mempengaruhi calon pembeli potensial.

Dengan demikian, jelaslah bahwa pemilihan strategi iklan dan juga stilistika iklan sangat memberikan peranan yang penting dalam sebuah iklan karena akan menyampaikan pesan melaui kreativitas yang tinggi dan televisi merupakan salah satu media yang dapat mewujudkan hubungan yang relevan antara tujuan produsen dan harapan konsumen secara cepat dan langsung. Di sini dapat disarankan kepada pembuat iklan untuk selalu memperhatikan target pasar dan konsumen yang ingin diberikan tawaran produk atau jasa. Begitu juga perhatian terhadap pesan moral dengan bahasa dan gaya yang unik bisa dijadikan pilihan yang menarik agar sebuah iklan tidak melampaui batas kewajaran seperti menampilkan karakter atau tokoh dengan pakaian yang sopan, bahasa yang baik, dan alur cerita yang tidak bertentangan dengan nilai moral. Dengan demikian, melalui iklan masyarakat bisa lebih terarah, terinspirasi, dan tidak tercemar pola pikirnya terutama bagi anak-anak dan remaja yang begitu cepat terpengaruh oleh apa yang ditontonnya.

\section{KEPUSTAKAAN}

Batey, Ian. 2003. Asian Branding: A Great Way to Fly. Alih bahasa: Abdul Wahab. Jakarta: Bhuana Ilmu Populer.

Durianto, Darmadi, Sugiarto, Anton WW, Hendrawan S. 2003. Invasi Pasar dengan Iklan yang Efektif. Jakarta: PT Gramedia Pustaka.
Effendi, Onong. 1981. Dimensi-Dimensi Komunikasi. Bandung: Alumni.

Hakim, Budiman.2005. Lanturan Tapi Relevan, Dasar-Dasar Kreatif Periklanan. Yogyakarta: Galang Press.

Karana, Novita Puspasari. 2007. Strategi KomunikasiMedia TelevisiuntukProduk Rokok Mild (Studi Antar Kasus: Rokok A-Mild, Star Mild, dan L.A.Lights). Skripsi; ITB Central Library.

Kompas, Kamis, 6 Maret 2003.

Madjadikara, Agus S. 2004. Bagaimana Biro Iklan Memproduksi Iklan? Jakarta: PT Gramedia Pustaka.

Pradopo, Rachmat Djoko. 2005. Kajian Stilistika. Yogyakarta: Universitas Gadjah Mada.

Roman, Kenerth, Jane Maas dan Martin Nisenholtz. 2005. How to Advertise: Membangun Merek dan Bisnis dalam Dunia Pemasaran Baru. Jakarta: PT Elex Media Komputindo.

Suhandang, Kustadi.2005. Periklanan: Manajemen, Kiat, dan Strategi. Bandung: Nuansa.

Sutherland, Max \& Alice K. Sylvester .2005. Advertising and The Mind of The Consumer: Bagaimana Mendapatkan Untung Berlipat Lewat Iklan yang Tepat. Penerjemah: Setia Bangun. Jakarta: PT Gramedia Pustaka.

Suyanto, M. 2004. Aplikasi Desain Grafis untuk Periklanan. Yogyakarta: ANDI OFFSET.

Verdonk, Peter. 2002. Stylistics. Oxford University Press.

Wibowo, wahyu. 2003. Sihir Iklan: Format Komunikasi Mondial dalam Kehidupan Urban-Kosmopolitan. Jakarta: PT Gramedia Pustaka. 
